\title{
24. CADMIUM/CALCIUM RATIOS IN BENTHIC FORAMINIFERS RECOVERED DURING LEG 112 ${ }^{1}$
}

\author{
T. D. Jickells, ${ }^{2}$ B. M. Funnell, ${ }^{2}$ and K. A. Young ${ }^{2}$
}

\section{INTRODUCTION}

The concentrations of dissolved inorganic phosphate in today's deep ocean waters of the world vary in a systematic fashion related to the circulation of deep ocean water (Broecker and Peng, 1982). However, phosphorus records in deep-sea sediments are difficult to interpret because of postdepositional changes. In deep ocean waters, cadmium appears to behave similarly to dissolved inorganic phosphate (e.g., Boyle et al., 1976; Bruland et al., 1978) and, hence, a historic record of cadmium concentrations in the overlying waters preserved in oceanic sediments offers one a method of reconstructing ocean circulation. Hester and Boyle (1982) demonstrated that a record of cadmium concentrations in overlying water is preserved in open-ocean benthic foraminifers. Boyle went on to use the cadmium/calcium $(\mathrm{Cd} / \mathrm{Ca})$ ratio in benthic foraminifers to interpret paleocean circulation (e.g., Boyle and Keigwin, 1985/86; Delaney and Boyle, 1987; Boyle, 1988). Applications of this technique have so far been confined to deep-ocean calcareous sediments, where apparently there are no major differences between $\mathrm{Cd} / \mathrm{Ca}$ ratios in foraminiferal species from the same depth. Here, we report the first attempt to apply this technique to sediments of the Peruvian shelf, a more complex oceanographic and geological environment than the deep ocean.

\section{Contemporary Oceanographic Setting}

Our samples came from Ocean Drilling Program (ODP) Site 684 at $8^{\circ} 60^{\prime} \mathrm{S}, 79^{\circ} 54^{\prime} \mathrm{W}$, on the Peruvian shelf, drilled in a water depth of $426 \mathrm{~m}$. The Peruvian shelf is currently an area of upwelling having high rates of primary production. Nutrient-rich water upwells from shallow depths $(\leq 200 \mathrm{~m})$, but this process is subject to significant short-term variability, such as El Niño (Barber and Chavez, 1983). This major variability affects only the upper $200 \mathrm{~m}$ of the water column (Leetma and Witte, 1984); thus, in waters deeper than $200 \mathrm{~m}$, longer-term changes may dominate the analytical signals. This area is also one of horizontal gradients in nutrient concentrations (Tsuchiya, 1985) and in the depth and intensity of the oxygen minima, associated with organic-rich sediments (Wooster et al., 1965), The extent of denitrification, and probably oxygen deficiency, may vary with time as a result of changes in upwelling or in the water-column ecosystem (Codispoti, 1983). We compiled measurements of dissolved inorganic phosphate concentrations in the area of Site 684 using two data sets. The first, based on water samples collected in 1960 and 1981-1982 (Tsuchiya, 1985, and pers. comm., 1988), offshore but within $200 \mathrm{~km}$ of the site studied (Fig. 1), and the second based on profiles from the shelf region approximately $1.5^{\circ}$ south of Site 684 (Fig. 2). Detailed sections of water-column profiles, collected from offshore onto the Peruvian shelf in this region,

\footnotetext{
${ }^{1}$ Suess, E., von Huene, R., et al., 1990. Proc. ODP, Sci. Results, 112: College Station, TX (Ocean Drilling Program).

2 School of Environmental Sciences, University of East Anglia, Norwich NR4 TTJ, United Kingdom.
}

indicate substantial changes in water-column concentrations in the upper $150 \mathrm{~m}$, but the changes below are small (Codispoti, 1983), although phosphate levels are slightly higher at the more southerly shelf stations.

\section{Sedimentary Environment}

The sediments in Hole 684B consist of $50 \mathrm{~m}$ of Quaternary and Pliocene siliceous oozes and silts that give clear evidence of anoxia. Throughout most of the core, large, thick-walled benthic foraminifers are rare, either because they cannot survive the low-oxygen conditions or because of post-depositional decomposition. However, at two horizons in the core, numbers of thick-walled benthic foraminifers increase dramatically. The reasons for this change are not obvious, but may reflect a change in water quality in the area. Another possibility is an increase in water depth at this site, either from a rise in sea level or subsidence on this unstable margin. Species of foraminifers are characteristic of particular depth zones, and we used this information to estimate the water depth of deposition of these horizons. There is, however, insufficient information to narrow this down completely, except to indicate it may range from 500 to $1500 \mathrm{~m}$. This suggests at least some deepening of the water relative to today's levels.

Shipboard scientists inferred deposition in the upper middle bathyal zone (at a depth of between 500 and $1000 \mathrm{~m}$ ) for the interval examined. Sample 112-684B-4H-1, 117-119 cm is co-dominated by Uvigerina peregrina (34\%) and Bolivina spissa (33\%); the latter species ranges from 300 to $1200 \mathrm{~m}$ off South America (Resig, 1981) and characterizes the upper bathyal and upper middle bathyal (500-1500 m) zone off Southern California (Ingle, 1980) at the present day. A depth of more than $500 \mathrm{~m}$ is indicated by this combination and is consistent with other species in the assemblage.

Sample $112-684 \mathrm{~B}-4 \mathrm{H}-7,11-12 \mathrm{~cm}$, is dominated $(84 \%)$ by the species, $U$. peregrina, which ranges from 700 to $1600 \mathrm{~m}$ off South America (Resig, 1981) and characterizes the upper bathyal (150-500 m) zone off Southern California (Ingle, 1980). Again, a depth of $500 \mathrm{~m}$ or more would be consistent with this and other species in the sample.

Both samples contain Nonionella miocenica (1\% to $99 \%$ ), which occurs in the inner-shelf $(0-50 \mathrm{~m})$ zone off Southern California. Its presence in these samples may indicate transport downslope. In the remainder of the sediment, benthic foraminifers are rare and dominated by thin-walled species. The thinning of shell walls is thought to be an adaptation to a low-oxygen environment. We have found that these thinwalled species are unsuitable for $\mathrm{Cd} / \mathrm{Ca}$ analysis, as the amounts of material are so small after cleaning as to make signal/noise ratios unacceptable.

\section{METHODS}

Sediment samples were sieved and foraminifers selected and identified, then cleaned, redissolved, and analyzed using the methods described by Boyle and Keigwin (1985/86). Cadmium results were corrected for the slight effects of variations in calcium concentrations. Full procedural blanks for cadmium were low $(<10 \%$ of sample values) and 
Table 1. Cd/Ca ratios in Site 684 foraminifers and inferred DIP* concentration in the overlying water.

\begin{tabular}{lccrc}
\hline \multicolumn{1}{c}{ Species } & $\begin{array}{c}\text { Core, sample, } \\
\text { interval }(\mathrm{cm})\end{array}$ & $\mathrm{Cd} / \mathrm{Ca}$ ratio & (n) & $\begin{array}{c}\text { Inferred DIP* } \\
\text { concentration } \\
(\mu \mathrm{M})\end{array}$ \\
\hline Uvigerina peregrina & $112-684 \mathrm{~B}-4 \mathrm{H}-1,117-119$ & $0.19 \pm 0.04 \times 10^{-6}$ & 15 & 2.3 \\
Bolivina spissa & $-4 \mathrm{H}-1,117-119$ & $0.24 \times 10^{-6}$ & 2 & 2.8 \\
Uvigerina peregrina & $-4 \mathrm{H}-7,11-12$ & $0.24 \pm 0.04 \times 10^{-6}$ & 17 & 2.8 \\
\hline
\end{tabular}

*DIP = dissolved inorganic phosphate; $\mathrm{n}=$ number of replicate analyses of foraminifers from each horizon. Uncertainties listed represent one standard deviation about the mean.

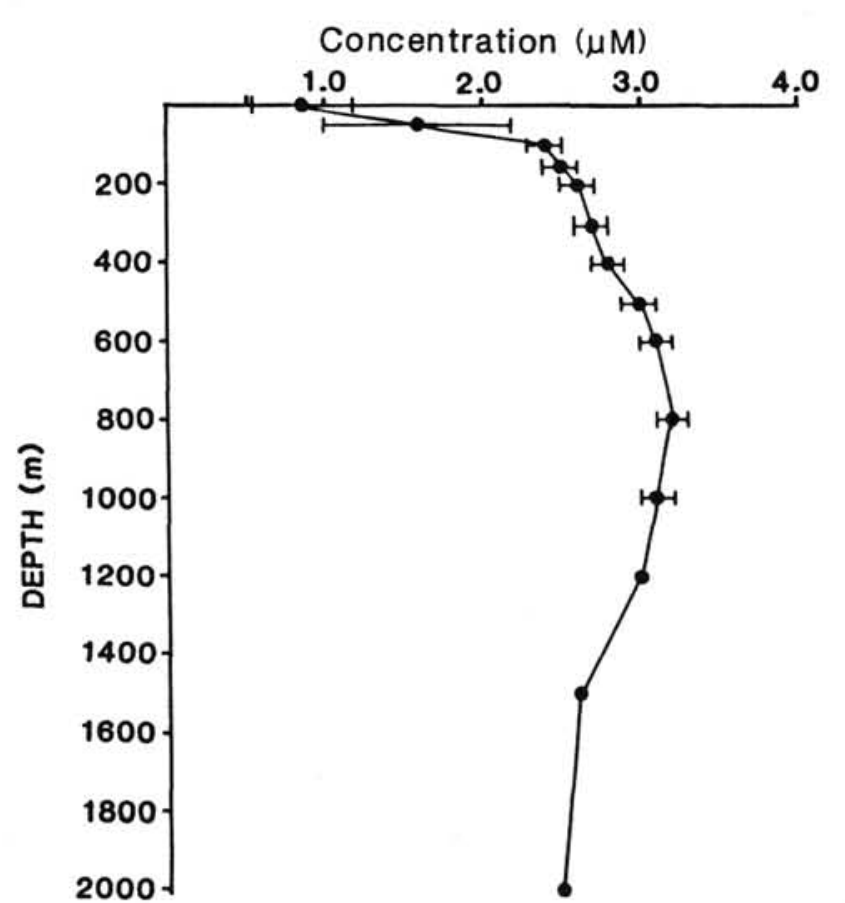

Figure 1. Modern profiles of dissolved inorganic phosphate concentrations from offshore in the region of Site 684. Profiles are compiled from 10 profiles collected in the area, eight in 1981-1982 and two in 1960; error bars represent one standard deviation about the mean (Tsuchiya, 1985, and pers. comm., 1988).

manganese/calcium atomic ratios also were low $\left(<10 \times 10^{-6}\right)$, indicating no interference from $\mathrm{MnCO}_{3}$ overgrowths (Delaney and Boyle, 1987). Thus, these analytical criteria suggest that our analytical procedures are satisfactory. However, insufficient samples prevented us from looking at possible diagenetic changes in the foraminifers by methods such as sequential dissolution of the test (Boyle, 1988), which might perhaps reveal effects of post-depositional migration. Although the tests seemed well-preserved, such changes could be significant in these reducing sediments, where we anticipate high pore-water-dissolved inorganic phosphate and cadmium concentrations.

\section{RESULTS}

Results are presented in Table 1. Also in Table 1, we have converted these $\mathrm{Cd} / \mathrm{Ca}$ ratios to dissolved inorganic phosphate concentrations in the overlying waters, using the relationship reported by Boyle (1988). Some scatter exists in the relationship reported by Boyle (1988), and this introduces an additional uncertainty, beyond the analytical uncertainty in the $\mathrm{Cd} / \mathrm{Ca}$ ratio, into our estimates of dissolved inorganic phosphorus concentrations in the overlying waters at the time of deposition.

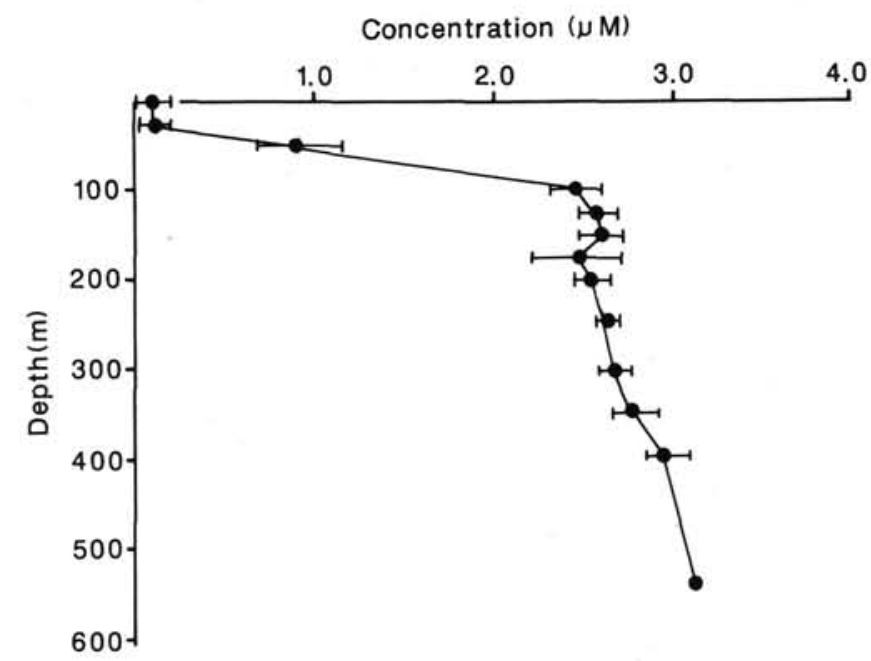

Figure 2. Modern profiles of dissolved inorganic phosphate concentration from the Peru continental shelf (Hafferty et al., 1978). Profiles are compiled from three profiles; error bars represent one standard deviation about the mean.

\section{DISCUSSION}

As noted above, results from this environment must be interpreted cautiously because of (1) the limited amount of analytical information, (2) uncertainties about any diagenetic effects in this environment, (3) complications in the conversion of $\mathrm{Cd} / \mathrm{Ca}$ ratios to estimated environmental concentrations, and (4) uncertainties over the depth and character of the depositional environment. A comparison of the inferred dissolved inorganic phosphate concentrations with the modern water-column profile (Figs. 1 and 2) suggests that our estimated paleo-dissolved inorganic phosphorus concentrations of 2.3 and $2.8 \mu \mathrm{M}$ (with uncertainties of about $25 \%$ ) are very similar to one another, with no significant differences between species, and also similar to modern values of 2.3 to $3.1 \mu \mathrm{M}$ in the depth range of 100 to $600 \mathrm{~m}$. Within the limited data available, one can postulate that when these foraminifer-rich horizons were deposited (approximately $3 \mathrm{~m} . \mathrm{y}$. ago), the chemistry of the overlying water was similar to today's water. However, given the rarity of such foraminifer-rich horizons, it is possible that they themselves represent unusual watercolumn conditions in this area at that time.

\section{ACKNOWLEDGMENTS}

We thank the ODP shipboard party for collecting the material, Geoffrey Eglinton for his encouragement, and Dave Pitman for his help with the early part of this study. We are grateful to E. A. Boyle for his help and encouragement. We thank M. Tsuchiya, who made unpublished Scripps Institute of Oceanography data from the Peru upwelling available to us, and E. Suess for drawing our attention to 
the University of Washington data. This study was funded by the U.K. Natural Environment Research Council ODP Special Topic Grant Number GST/02/251.

\section{REFERENCES}

Barber, R. T., and Chavez F. P., 1983. Biological consequences of El Niño. Science 222:1203-1210.

Boyle, E. A., 1988. Cadmium: chemical tracer of deepwater palaeoceanography. Palaeoceanography, 3:471-490.

Boyle, E. A., Sclater, F., and Edmond, J. M., 1976. On the marine geochemistry of cadmium. Nature, 263:42-44.

Boyle, E. A., and Keigwin, L. D., 1985/86. Comparison of Atlantic and Pacific paleochemical records for the last 215,000 years: changes in deep ocean circulation and chemical inventories. Earth Planet. Sci. Lett., 76:135-150.

Broecker, W. S., and Peng, T-H., 1982. Tracers in the Sea: Palisades, NY (Lamont-Doherty Geological Observatory).

Bruland, K. W., Knauer, G. A., and Martin, J. H., 1978. Cadmium in northeast Pacific waters. Limnol. Oceanogr. 23:618-625.

Codispoti, L. A., 1983. On nutrient variability and sediments in upwelling regions. In Suess E., and Thiede, J. (Eds.), Coastal Upwelling Part A: New York (Plenum Press), 125-141.

Delaney, M. L., and Boyle, E. A., 1987. Cd/Ca in late Miocene benthic foraminifera and changes in the global organic carbon budget. Nature, 300:156-159.
Hester, K., and Boyle, E. A., 1982. Water Chemistry control on cadmium content in Recent benthic foraminifera. Nature, 298:260-262.

Ingle, J. C., 1980. Cenozoic paleobathymetry and depositional history of selected sequences within the Southern California Continental Borderland. Spec. Publ. Cushman Found., 19:163-195.

Leetma, A., and Witte, J., 1984. El Niño Atlas 1982-83: Miami (NOAA/AOML).

Resig, J. M., 1981. Biogeography of benthic foraminifera of the northern Nazca plate and adjacent continental margin. Mem. Geol. Soc. Am., 154:619-665.

Tsuchiya, M., 1985. The subthermocline phosphate distribution and circulation in the far eastern equatorial ocean. Deep-Sea Res., 32:299-313.

Wooster, W. S., Chow, T. J., and Barrett, I. 1965. Nitrite distribution in Peru current waters. J. Mar. Res., 23:210-221.

Date of initial receipt: 10 August 1988

Date of acceptance: 5 July 1989

Ms 112B-195 